\title{
Writing the in-between spaces: Discovering Hermeneutic-Phenomenological seeing in Dadaabi Refugee Camp, Kenya
}

\author{
Wills Kalisha, NLA University College, Bergen
}

Email: kalisha.wills@gmail.com

\begin{abstract}
In this paper, I explore my journey of discovering the meaning of pedagogy and phenomenology as a research methodology while doing my master's thesis. Like new researchers in any field, we have a journey that we travel which is often marked with uncertainty and a lack of clarity, especially with regard to methodological considerations. I describe what seeing pedagogy entails for me as I write phenomenologically. I also outline the difficulties and tensions present as I weave my way into writing. I use personal examples of struggles that I encountered in the writing process that are characteristic of phenomenological methodology.
\end{abstract}

\section{Introduction - The Beginning}

A few years ago, I was a teacher in a number of high schools in Kenya. During tea or lunch breaks, my colleagues and I would talk about our students and other issues that concerned us. The conversation below reflects how teachers in the staff room talked about students:

"I need to repeat my lessons a million times before they understand. These ones are dunderheads!" One teacher noted with anger, "I have to use a cane for them to do their homework and assignments. They have no idea that they need to pass their exams for them to be somebody in this world today!" Another quipped from the other corner of the staffroom. "In this school, we have below average students, they come here when they have no idea of how to even write their own names, should I start by teaching them to write their names or teach them Swahili as it is in the syllabus"?

This seemingly casual exchange in the staffroom uses language that reflects our frustrations with teaching students in this school. Was this the way our students really were? In a pedagogic sense, we were talking about what was going on in the classrooms, yet we offered no solutions to one another; rather, we left the examples we shared for individual speculation and reflection. These conversations, though animated, remained only as conversations; there was no time for intersubjective reflection on our "tacit knowledge to make it explicit" (Henriksson, 2008, p. 24). Our feelings of pain, remorse, and fear could be felt as we conversed. There was a hidden frustration in the system we were in, as it blinded and frustrated the desire in us to see children as unique and different.

Since the Kenyan schools I taught in were district schools, they could only accept students who had not qualified for entry into national and provincial schools ${ }^{\mathrm{ii}}$. We saw our students not as highly qualified, but as "rejects." They were at the mercy of me, the teacher. Resources in such schools were limited. Teachers and their authority were unquestioned; as 
teachers, we considered education to be something that the teacher gives to students. Education became a commodity sought after by the student. I understood pedagogy narrowly to mean the teaching and learning that happens in classrooms. This was in contrast to a didacticiii classroom where the teacher lovingly helps students to gain access to knowledge, where the teacher also listens to students' struggles, knows tactfully when to use a glance; when to rebuke a student; when to compliment; when to stimulate learning or when to answer a student's question and when to be quiet. I thought students were privileged to have a teacher in class and not the other way round.

On numerous occasions, I asked myself why I was a teacher. Was I treating students the way I was treated as a student? Whatever I said in class was final. Students had opportunities to ask questions, but only questions that were limited to what they had not understood in my teaching. New insights or original thoughts were not welcome. At this time, communication between teacher and students was not for "meaning making" (Biesta, 2013, p. 28); neither was it for "bringing something new that was not there" (Biesta, 2013, p. 6). Teaching meant passing information from the teacher to students. To me education was merely seeing students participate in schooling activities to achieve a future goal. There was no meaningful pedagogical relationship between students and teacher. The assumption was that students had nothing to teach us. Teachers knew all; students were invisible and insignificant. Students would correctly say this of teachers just as Ellison observes:

When they approach me, they see only my surroundings themselves, or figments of their imagination - indeed, everything, and anything except me. That invisibility to which I refer occurs because of a peculiar disposition of the eyes of those with whom I come in contact. A matter of the construction of their inner eyes, those eyes with which they look through their physical eyes upon reality (Ellison as cited in Henriksson, 2012, p. 125)

How was I supposed to see these students differently, given that most of my fellow teachers were also seeing them as I was? With this attitude, the world of the student is reduced to a receptacle, a 'container' of what is taught (knowledge). My words in class seemed void and to be spoken without reflection and questioning. Or were students questioning silently refusing to question me? Although this to me seemed to be a good sign that they have learnt something (by being quiet), it was unlikely to have been the case for the students. I made the world of the student rather "small, drab, and dull" (p. 130) and in a way making the words of Adrienne Rich true:

When someone with the authority of a teacher, say, describes the world and you are not in it, there is a moment of psychic disequilibrium, as if you looked into a mirror and saw nothing (as quoted in Henriksson, 2008, p. 24).

What kind of world was I creating for these particular students? I planned for lessons, adapted materials for use in teaching, developed courses, taught and evaluated students in an unreflective and naïve manner. Did I have the time to think and reflect on my actions? Did I understand why I was teaching what I was teaching? I thought I did until slowly, and hesitantly I started coming to moments of seeing - catching glimpses of how the child should be seen. I began to wonder - had I begun attaching myself to my students in search of a way that I wanted to know them, to understand them, in order to make the situation better? Phenomenologically speaking, for me this was the starting point of thinking about and feeling what education should or ought to be.

How might I learn to research and write phenomenologically about my experiences and the experiences of my students, and do so without losing methodological rigour? What ought I to do in order to write as evocative and moving as is required in phenomenology? 
These questions lingered in my mind as I set out to do my masters research in the Dadaab refugee camp where my main focus was on the meaning of pedagogy and belonging as lived by girls and their teachers in the refugee schools ${ }^{\text {iv }}$. Yet the question I was to ask was not immediately accessible to my mind, but hidden in many diffused suggestions and possibilities available in the initial writing. The question was to be relevant to me, touch me and invigorate me to bring out new knowledge. I developed cold feet and had moments of ambiguity when nothing seemed to make sense. The journey was often marked by periods of darkness, where whatever I wrote seemed misty and unclear. Even more difficult was where to start this journey. I have crossed two educational traditions ${ }^{\mathrm{v}}$. This crossover put me in a sort of disequilibrium, a middle ground or an in-between position. This position meant that I had to choose between leaning either on the side of tradition or to choose to listen to myself, to learn a research methodology that will speak to the existential meaning of what research is and should be educationally. In this paper, I choose to reflect on this methodological dilemma and dual position as I weaved my way into seeing pedagogically and writing phenomenologically.

\section{Hearing the pedagogical question; Moments of indecision}

My goal was to get to an understanding of what my actions meant to the students, and to embrace reflective thinking about the experiential meanings of education. Rosemary, one of my students at my school, confronted me one day. How was I to make sense of such an experience as this?

The day began like any other day in school. I arrived very early in the morning, at around 0620 hours, for an early morning lesson with form 3B students. Early morning lessons are popular with teachers at this time of the year, because they are often necessary for completion of the syllabus. I expected by this time to find assignment books on my desk so that I could evaluate them before going to teach. To my amazement, there were none there. My day had already been ruined. I felt angry; I felt that I should go to class and give them a very stern warning. They should take their academic work seriously! I considered how I had 'wasted' my morning by coming in early to evaluate assignments that were not there. Should I punish these students? What kind of punishment should I give so that this behavior is not repeated? It was common in this school for teachers to punish students. That included caning.

While I was still thinking, one of the students, Rosemary stood rather trepidatiously at the door of the staffroom. I did not bother with her. I was about to walk past her when she said, "Excuse me sir". Her voice was shaking, but she was determined to say what she wanted to say. "I have come to be punished". This took me by surprise. Then she readied herself for a cane lashing. I looked at her and wondered whether she was ok. Was something wrong with her? "Rosemary, what is it?" I asked. "Teacher, I haven't done your assignment yet, so just go ahead and punish me here so that you don't have to worry about you embarrassing me in class in front of other students".

I was mum for a moment. What should I do? I had seen her in class only as a quiet girl with a sometimes 'I don't care attitude'. I had overheard other teachers' say that she is a poor performer; a careless girl who is afraid neither of being punished nor of failing. I stood there for what seemed a long time, looking at her laying on the floor awaiting the cane. I did not know what to say. She spoke up, saying "Look, we hardly have any books on Swahili poetry in this school - the only copy available you have it. We can't borrow it because it is the teachers copy. My parents can't buy a 
copy for me, because all the money they have is spent on food and paying for my school fees. Coming here is a sacrifice. I climb those two hills and meander through that lonely forsaken valley to reach here. By the time I am here, I am already tired and exhausted. I should do your assignment at home, but how? A lot of chores await me on arrival at home. None of the people at home understand that I should study and pass exams, yet you demand I study and pass. I think am tired of being in such a messed up system. Do whatever you want to do with me".

How else could Rosemary have approached me and shared her frustrations? Seeing this shaken girl shook me. I questioned my attitude - that I had taken for granted for so long - of being in charge. She had shattered my understanding of what schooling meant for students like her. Had I thought of how this might be a "messed up system" before, or was I just used to it? Had I, in the end, messed up the students? Her words, citing a "messed up system" left me feeling that I was indeed a big part of the mess. She confronted me with such bewilderment that I wondered and kept asking myself, "What kind of life should we present to children?" What are we presenting as 'education' to these children? What is it like to them? What did education really mean to Rosemary?

The more I thought about this incident the more I realized that this girl had provoked something deep in me. I began to question what education really meant. Was the system in which I was working, for both me as a teacher and for this girl, truly operating to educate rather than to control? I was in a predicament. I had a choice to make. Dealing with children entails many forms of responses; some could be automatic, while others involve hesitation and doubt. I needed to make a difficult decision, one that involved relinquishing my hierarchical authority and allowing myself to be responsible for the vulnerability of this child.

Later, while working on my master's thesis I read Langeveld, who asks "How many generations or centuries does it take until a reflective, systematic, and engaged form of thinking emerges which directly or indirectly makes a real difference in the practical acting of everyday life?" (1983, p. 5). It was this question that kept unsettling my thinking and brought me to reflect on what it means to be with children and to teach them. What would it mean to be involved equally also in children's everydayness, their daily trivialities of life? Does the everyday living with and being with children give teachers any sense in trying to understand their world? Does it help us to teach them better? My resolve was slowly taking shape. Van Manen (1990) encouraged me this way,

"And since to know the world is profoundly to be in the world in a certain way, the act of researching - questioning - is the intentional act of attaching ourselves to the world ... to become the world" (p. 5).

Through these thoughts and questions, the journey was slowly taking shape.

\section{Specifying the question}

My thinking was challenged and broadened further as I prepared my masters proposal and when I read van Manen, Biesta and Sævi, the latter being my supervisor. They present an existential understanding of education, based on education as an encounter of unique, different and equal persons. Although the teacher and the student have different tasks, intentions and responsibilities, all of the persons involved are fundamentally equal in that they are persons. Scholars like van Manen and Biesta see each person as unique or Other and that each should be respected in their uniqueness or Otherness - all the while paying keen attention to their being and becoming (Kalisha, 2013b, p. 2,) 
With an aim to furthering my understanding of phenomenological methodology, I decided to read phenomenological texts that dealt with the subject of pedagogy. The existential understanding that I gained from the authors mentioned above seemed paradoxical and difficult to understand at first. Both van Manen and Sævi claim that the relationship between student and teacher is "asymmetrical" in nature. The teacher is responsible for the student. However, this responsibility should be understood in light of being responsible for the Other ${ }^{\mathrm{vi}}$ - where the Other, the student is the "master and the task giver" (Henriksson, 2008, p. 20). By virtue of the student being a minor, and vulnerable, I as a teacher am called to be responsible for his/her vulnerability. I am moved to be there for this child in this situation, to act in a way that the child wishes and desires. This forms the basis of my pedagogical reflection and acting. With this approach, the tasks emanate from the child.

How is it possible that the students should give me tasks to do? How can this work? This was hard for me to grasp at the beginning. At the core of pedagogy, lies the dilemma for teachers like me; as van Manen puts it, "pedagogy is involved in all our active and reflective distinctions between what is good and what is not good for a child" (van Manen, 1990, p. 23). Sævi, (2005) and Henriksson, (2008), further clarify this point by taking us back to the meaning of pedagogue in ancient Greece. A pedagogue then was a slave who accompanied a child to school. These authors claim that the slave supervised the child to ensure he lived as per what he learnt in school. This meant a relationship that was, at the same time, "asymmetrical, yet reciprocal". They "simultaneously were leading and being led, supervising and being supervised" (ibid: 21). How far had I fallen from this understanding?

To be completely transformed in my belief system and to accept pedagogy from the continental tradition required me to dwell continuously on this phenomenon. I needed to allow it to speak to me as I read and re-read the writings. Pedagogy, Wivestad says "lacks the signals of an academic discipline" $(2014$, p. 7$)$; it takes its starting point in the concrete lifeworld of the child and finds its life-line in upbringing of the child at all stages of development. It blurs all formal and informal boundaries of home and school (Sævi, 2011). "Pedagogic, as a short form of paidagogike techne, combines in the same way both the practical ability in normative principles for and theoretical study of paideia, i.e. upbringing and Bildung" (Wivestad, 2014, pp. 6-7). This understanding kept disturbing the meaning that I had taken for granted for so long - of education as schooling or just the goings on in institutions of learning. It put instead at its centre the moral questions behind the situations as experienced by individual children. While doing my research, my concerns for my participants broadened further to include life in general and not just school.

With all of this thought provoking reading of phenomenological texts that expounded on the meaning of pedagogy, I thought I had come to understand pedagogy. But I thought nevertheless, "Can pedagogy ever be understood unless it is lived?" I resolved to ask myself "What would pedagogy mean to students in refugee contexts?" This question became the leading light as I struggled to describe and understand what pedagogy really meant to the girls whom I was going to interview in the refugee camps. I wondered whether I truly understood or whether I was simply curious. My interest as a researcher was to go beyond mere curiosity to a moral/ethical dimension - one that reflected on and showed concern and care for my respondents and their experiences; one that is guided by both wonder and bewilderment.

\section{Moments of decision in the field}

How then does one hear phenomenologically and then respond to it? While doing fieldwork at the Dadaab refugee camp, I encountered secondary school girls daily. I saw what they were going through. Some of their experiences were hard to write down. How can one write and 
describe fear, anger and worry? At the time, I did not know how to begin; phenomenology had not yet made sense to me, though pedagogically speaking, I had been awakened to its nature. I knew that I should start from the lived experience, (Van Manen, 2003) but my moment of epiphany had not yet come.

While in the field, I had an experience that contributed to my decision to use phenomenology as my methodology. As Sævi, (2014), says "methodology requires a reflective attitude that gives rise to methods and that gives research its direction". (p. 1).

Stella, a student in one of the schools I visited, was punished for coming late to school. Afterwards, she told me:

"I travel for about an hour to school. I have to go though some places that are very dangerous for me as a girl, yet the teacher does not know this. I come to school and find him waiting for the late comers at the gate to punish them. He does not ask any questions; his stern face throws you to the ground. The next thing you know are lashes of the cane, sometimes it pulls your hand towards him, and you receive your punishment and go. I have always been a late comer, so am punished quite often for coming late. I have explained to him but he does not get it. Sometimes I feel he should have been made a girl in this situation. Therefore, I just comply, am punished, come, go home, and back to school, until all this cycle will be over some day ${ }^{\text {vii", }}$

I was floored by what she told me. At first I tried to reason with the teacher but that did not help. While in my room that night, I wrote my observations for the day. I attempted to describe the episode, but could not do so in the manner required by conventional qualitative methodologies. I struggled with the incident and remained speechless for a while. I wrote her words down one by one, trying to make some rhyme schemes out of these words - to form some rhythm or a poem. I kept wondering how this could make any sense, and more specifically, I wondered how I could possibly produce a well-written text that was acceptable and understandable. More importantly, I wondered how best I could help her, Stella who seems, in the eyes of her teacher, to have no identity and, in his eyes, defenseless.

I have witnessed similar episodes many times. They have all reminded me of what pedagogy ought to be; that it should be an adult leading a child, guarding her potentialities and identity. Pedagogy is personal, asymmetrical, and responsible for the well-being of the young one - who needs the caring guidance of an adult to protect her in her dignity as a human being. I reached out to phenomenology. Phenomenology is sustained by this "vague and the equivocal, the quote and the collage, the question and the provocation, the void and the vision" (Cooley sited in Henriksson \& Sævi, 2009, p. 39). I could no longer stand aloof. I needed to write not just about the incident or data as collected in the field, but to write of the experience itself. This girl is living this moment together with her peers and teacher(s)! This episode turned my thoughts upside down and threw my methodological considerations which at that moment were not yet well defined - into much disarray. Something very important was missing in my methodological considerations. After going through my field data notes, written observations and log-frames, I made up my mind to go through my data repeatedly more carefully in an effort to make sense of it. It was at that moment that my mind became clear that phenomenology was the methodology to use.

\section{My writing process- moments of meaning}

After completing my fieldwork, I recall a moment in which I was seated, thinking deeply about how my thesis writing was progressing. I was in something of a depression because all of the drafts that I had attempted to that point had not come out as I intended. I felt betrayed 
by myself; I was not 'producing' what I really wanted. I sat around my reading table in the house. On one end of the table was one of the drafts I had just received from my supervisor. I had had a discussion with her about it. She had explained tenderly and caringly how I should understand pedagogy, pedagogical relation, pedagogical moments and pedagogical situations in order to write more pointedly. That discussion was still alive in my mind. I had written in a rough, sketchy, shallow manner on what I thought was the meaning of pedagogy and belonging. In my mind were mixed up opinions and undefined terms that lacked any pedagogical quality relative to the meaning of being human in a classroom context. At the end of the paper was a comment that glared at me, that kept wending back to me as I reflected on our discussion. It read "Kalisha, in your own words who is a human being?" "So, Kalisha who are you? A human being?" After reading the comment, my wife said, laughing, "Maybe you need to write about yourself". I thought, "What does it meant that I am human, and how am I to write about myself? My writing is about refugee girls, not about me."

Then my glance swept across the room. I cast much of what was there to the background. One photograph refused to escape my attention; our wedding photograph. The emotions that came with that attention rekindled a desire to see more of the old photographs that we had. I suddenly started to feel a kind of homesickness. On the first page of the 'home album', I stumbled on a picture that struck me hard. Standing out from this photo is a certain pointedness. Protruding from the bottom was a bit of text. It read, "Real Life".

In the photo, I was holding green leafy branches that I had brought from the forest to feed our goat. The goat was standing beside me. The words suddenly became suspended beyond my grasp. I felt captivated by them and they added to my wondering. I looked at the kitchen table in the house just then and saw some green leafy vegetables and fruit in a bowl that my wife had bought from the international store. The experience of seeing such green vegetables or branches is not new to me, but the words on the photograph were still haunting me. Memories came flooding up:

"Kalisha, that one is mine" John calls. I run to see a succulent ripe guava protruding from a slippery tall tree. The tree is not easy to climb; the guava hangs loosely from a thin branch that cannot support either of our weights. We gaze at the fruit hoping that we can make it fall down. We attempt stone throws but they fail. With no ladder to climb, we give up and go on to graze our parents' cattle.

This was real life then when I was a boy. I lived there, the place that I could see on the photo. I was moved with nostalgia to look upon it. Deep within me, I felt "I belong there, I want to go there and see, to try re-live that kind of life." Still, I can do so only as a reminiscence of what used to be. Do I belong there? Or is it here, now, where I live and study? "What does a mango tree look like Kalisha?" "Do you have coffee farms?"

"What does a coffee tree look like?" was a question asked by a teenage boy whom I met when visiting friend's for dinner here in Norway. Does seeing a real mango or coffee tree mean life is real there? "Life here is so unreal, we only get frozen products, have no experience of plucking the mango fruits or coffee berries. I wish I were in your country", the teenager said.

"In your own words Kalisha, who is a human being?" The degree to which that question provoked me to think was profound. It brought an upsurge of thoughts and memories that I would not otherwise have recalled; it welled up existential questions that became the beginning points of my wondering just who I am and where I belong... questions that I had to answer before I posed the same question to my respondents. There emerged a definite tension in me. I thought of what I knew - the taken for granted photos and all that was in my house and all of the things that I did not know. The meanings that came to me kept emerging from my wondering. Was I losing my mind? Where was this kind of questioning leading me? 


\section{Encountering the meanings in daily encounters.}

In the afternoon of that day, I took a walk along the banks of Uppsala River in Sweden ${ }^{\text {viii }}$ near the hotel I was staying. Standing beside the river, I saw many people gathered on the banks - both old and young - chanting cheerleading songs, "Go team, go team"! In the river a group of young and old, men and women, were kayaking. It was a competition that has been a tradition in this place for many years. I knew no one here on the banks of the river; the sport itself was not very appealing to me. But I was interested in seeing the beauty of the competition between the teams, especially the old folks. After a while, I began wondering whether I had come here because writing had become difficult for me, or, rather, was it because of the recommendation by my contact person? The following day in the Institute's office, I met the coordinator of the research program that I was on. She asked, "Kalisha did you enjoy the games yesterday?" I paused before answering. I was pondering what my response would be. Should I say yes for the sake of it, so as not to disappoint her for inviting me? Just when I was about to speak... "I know you might not have enjoyed because you are an outsider. You know we love it because it has been a spring festival for ages here."

At this point in the writing process, I felt bereft of words to write. The thesis that I had planned to write about was not coming to be. I had spent a lot of time writing and re-writing working from the many possible themes that were emanating from the data. I had thought that I had it all figured out. The difficulty - and I was finding that it was a huge difficulty - was to discuss the lived space of the refugee girls. Did the girls belong to the camps, the schools or to outside? I was stuck. Then, something I experienced - the kayak races themselves resonated with me deeply.

Van Manen (1984, p. 13) says to do phenomenological research... is "to ask questions of life, of the way we live and experience life". The way we experience the world and live comes to us consciously - although un-meditated and, sometimes, through daily taken for granted ways. The German equivalent of experience, erlebnis, contains the verb leben meaning living through something, (van Manen, 2003, p. 579). In living through something, we are forced to step out of it in order to allow it to address us.

I had brushed the episode behind in my mind, yet I recalled it again the following day and again it stood out disturbingly for me to see. A lived experience has a characteristic roundness (Bachelard, 1964). As Gadamer says, "if something is considered an experience, its meaning rounds it into a unit of a significant whole" (Gadamer cited in Sævi \& Eilifsen, 2008 , p. 3). This roundness of an experience, "prevents it from blending in with the rest of our lives, making it stand out, distinguishes it in our memory as a meaningful event for us". Though the kayaking episode seemed casual and 'by the way,' I endured it, saw its joys, sorrows, fears, worries, cares -all of which were prior to any thought or reflection in the moment of experiencing it. The experience struck me and engulfed all of my being in the moment of its happening. I did not ask, "What am I experiencing?", but, "what is this experience like?" The sight of people kayaking was new to me, but I allowed myself to be taken up by it. Dilthey says of experience, only in "thought does it become objective" (Van Manen, 2003, p. 579). The coordinator's comments the next day - of me being an outsider awakened the thought in me of thinking about the experience and objectifying it, opening my mind to the "unforeseeable"- that is, being able to hear the comment and allow it to come into being as it comes into being. (Sævi, 2013). What did it mean to be an outsider or insider?

Can I be both an insider and outsider at the same time? As a researcher, how much of the inside or outside of an event or an experience should I be able to see? How much of the inside and outside should be part of the research process? We live in a continuum between being inside self and outside self in our struggles to belong. Our alternating between being inside and outside is part of our being in the world. It cannot be overcome by being on either 
side. And, as Bachelard, (1964) says, “And if we want to determine man's being we are never sure of being closer to ourselves if we "withdraw" into ourselves [...] Sometimes it is in being outside itself that being tests its inconsistencies" (p. 215). Indeed being out of the comfort of my country and school, caused me as a person realize the lived meaning of both being on the inside and outside. Yet there was a big existential difference between an insider (one who knows a place to the extent that the daily-ness disappears) and an outsider (metaphorically - a visitor, who destabilizes the status-quo or daily-ness).

Can I occupy a middle ground where I can enjoy the kayaking while at the same time dislike it? Or are there moments when I am an insider on the outside who occupies a space where s/he is not wanted? Or am I an outsider who is an insider where I occupy a space that is not mine but nevertheless I am in it? As a phenomenological researcher, can I occupy a middle ground?

In the middle, I am in a twilight zone, "where space is neither dark nor bright, where one is not inside or outside" (Sævi, 2005, p) -an in-between space; a liminal space (Linda, 2007). It is a fluid zone that allows passage. Phenomenologically speaking, this space is hard to inhabit yet it is necessary. The project of writing phenomenologically is called "an impossibility that is possible", "a search for what is basically undoable or impossible", (Sævi, 2013 , p. 5). In doing this kind of research and writing, one is able to move in the experience, feel it, enjoy or endure it and move out of it to reflect on it and write of it. Phenomenological writing is sometimes undefinable, not easily grasped and hard to come by. Heidegger says, "The closest appears therefore as is it were nothing. We see first strictly speaking, never the closest but always what is next closest" in (Sævi, 2005, p. 238). How could I have known that being an outsider on the banks of the river would alert me to the appropriateness of and possibility for phenomenological writing? My ability to dwell in the fluid state that allows movement in and out of the experience gave me the chance to see what is closer in a lived experience even though I might not see it entirely.

The experience of kayaking and reflecting phenomenologically on it pointed me towards the refugee girls whom I was writing about in my thesis. They too lived in an in-between state, between childhood and adulthood. A state where the (real) self of childhood is going through personal identity formation and discovery of where one belongs. Therefore, they need to be treated with pedagogical care and concern beyond mere classroom instruction. In other ways, these girls are in between in even more important ways. These girls are refugees. They are experientially, physically and geographically also in-between. They are in-between the transition from their homeland to a new location - a location that is presently unknown to them. Their very location is problematic, full of difficult moments, deprived of information. They are in a time of mediation, contestation and negotiation. They live in an encamped (Loescher \& Milner, 2006) area far and also distinct from other local people. They are in actual sense physically outside their own country (Somalia), and geographically inside a foreign country, Kenya. They are kept apart from, and are therefore outside the reach of, other Kenyan students with whom they, for instance, will sit for a common national exam. The refugee camp is placed at the border, in-between the two countries, a kind of a non-place. In order for me, a researcher, to be able to come to terms with this in-between-ness, I had to develop a phenomenological attitude that considered the meaning of inside/outside space, of in between-ness. Research at this point meant a caring concern for not only my own experiences but also for those of my respondents. Without that, I would not be able to describe and represent their voices in writing.

As I reflected on some of the concrete experiences that I encountered while writing, I pedagogically placed myself in the situation in which my respondents found themselves in. I bracketed my assumptions in the possible experiences that they were having and allowed meanings to emerge into and percolate through my writing process. In this way I was guided 
by the phenomenon as I wrote and described its lived sense for my respondents and myself. I was moved and impressed; my way of experiencing language had changed ... meanings started to erupt. I enjoyed the way the phenomena led me on. On numerous occasions, I encountered a blank page that refused any attempts to write on it. Yet the more I dwelt on the phenomena, took a pause and came back empty to start again, the more I got fresh insights and recalled incidents that spoke to the phenomenon I was living and was consumed by at the same time. At the end of it, out came a text - one that I could not believe it took so long to come by.

\section{Openings to meaning and the uncertainty of writing}

As a researcher, I had a plethora of questions to pose in order to reach an end that I had in mind - finishing my master's thesis in time. Coming from a background where market and consumer laden language feeds research interests, I had a very strong desire that the paper done in good time; that knowledge be produced and a good grade given to enable me get a job thereafter. There were the societal goals vis-à-vis personal desires. Nevertheless, as I reflected and began to wonder, the questions that I posed to myself became too heavy and forced me to the margins of educational research, the forgotten way of being and doing research educationally (Mollenhauer, 2014). Heidegger says "Questioning builds a way" (quoted in Friesen \& Irwin, 2014, p. 1). The understanding of Heidegger's 'Questioning' by Friesen and Irwin is one that "does not involve certainties or even specific answers". The 'way' is more than reaching goals or personal ambitions; it is like what Michael Ondaatje says, "Meander if you want to get to town" (Ondaatje, 1987, p. 146). It is highly unlikely that this 'way' is a possibility that many could dwell on comfortably. It involves meandering through crevices dark and shadowy yet full of possibility, of taking on a journey that one only has in glimpses where the destination might be. Yet we keep on moving and questioning as we build the way. To question and live the question in such a way that the question envelops one, or that one becomes the question, is "to learn to live and be in the uncertain and unknown not just for a short excursion 'out in the wilderness', but as a lifelong travel and a way of living". (Hansen, 2010, p. 161). The temptation for me as a researcher on such a way was to find an easy way to ride on as fast as I could. But the way that I was following here one that I now find myself in, caught in wonder - is one that Gadamer says "open(s) up possibilities and keep(s) them open" (Friesen \& Irwin, 2014, p. 1, emphasis in italics mine).

How then do I keep the question open? It is only language that speaks through my writing that opens the surface for things to be themselves. Questions arose as I wrote, but they were not to be answered entirely; they only cracked the window to let in fresh air (Linda, 2007). "Speaking means letting something emerge, letting something show itself, by naming something as something" (Sævi, 2013, p. 4). My wandering through albums - and as I walked around the city or on the mountain - yielded certain mental and emotional pictures that could only be seen, felt and read if I wrote them. This reality is equally embodied in our being and how we relate to what we see, encounter and experience.

Doesn't this way of thinking push us to the margins as we attempt to write? Margins or borderlands "[are] certainly a place that nurtures my creativity and imagination, since there are few rules and a lot of room for improvisation" (Becky as cited in Linda, 2007, p. 9). On the margins of pages or drafts of my papers, you will find scribbled writings of thoughts and reflections that came to mind as I read a text, pictures drawn that reminded me of a phrase that I read, or something that connects meanings gathered over time. We literally remember on the margins. Yet on the same margins lie all that stinks in a literal sense. Where I come from, garbage is sometimes thrown on the margin of fences. Still, when observers of 
landscapes want a clear view of the landscape, they go to the edge or the margin to observe the whole clearly. It is here that things present themselves as they are, in their "that-ness".

It is here on the margin that we find possibility to write what we have reflected on or wondered about as we read. As a researcher, I found myself on several occasions lost deep in reflections that did not make immediate sense - yet the sensuous was to see the reflections as being marginal. The margins were points of reconnecting with my understanding of the texts as expressed in drawings or words. Sometimes I wrote drafts that had no phenomenological potential yet I thought at the time that they did. At this point, my supervisor was the watchful guide, bringing me back to my interpretative senses so that I did not distort things as they are. Sometimes the feeling of being brought back to my senses was overwhelming. I felt as though my thoughts were being snatched away. "Kalisha, try to go deep here", she would write on my draft.

The pictures in my album had never made more sense to me than they did on that day by the river. I had seen people paddling in rivers before, but the kayaking that I saw struck me differently. I sensed a certain attunement with and wonder at what exactly it meant to belong - both during the time I recalled in the picture of me and my goat and now, inside or outside while in Sweden. The questions I asked moved me into a state of wonder that brought forth the glimpses of what belonging could mean first to me and then to the girls whom I was trying to describe. This way of looking at research started to make sense to me as I wrote my master's thesis. Only when the phenomenon touched me in a way that I felt it, experienced it and lived it was I able to write well about it. This way of writing new to me, earned me a glimpse into what phenomenological writing could possibly be. My writing started to change; I started feeling a difference in my language "that I could neither grasp nor reproduce" (Sævi, 2013, p. 2). It continued to grow and develop as I wrote the paper. This way of writing grew with a lot of hesitation and longing in me for the text to 'come'. It took a lot of patience to wait, look at life much more differently than I had been used to. I attended to daily occurrences with a new keenness and wonder. I found myself engulfed in finding the lived meaning of words, phrases, episodes and encounters that I experienced or that my respondents shared with me. I kept asking myself throughout the research process what this or that experience would mean to my respondents - children (minors). It was an attitude far from the one I previously had. I allowed myself to keep living the pedagogical question of belonging as I researched it and attended to the writing with a language that was my own. This way the phenomenon of research guided my writing beyond what I thought I could ever produce.

\section{Writing the meanings}

"Kalisha, how far are you with your work? I have not heard from you in a while. Please let me know if you need my help." That was a message I got from my supervisor after two months of silence. I could feel my heart thumping and pounding in my chest. I'd think, "When I go back to school, she is the first one I must meet! I feel like I should vanish away." I had written, in the previous two months, two drafts that I had discarded because they did not make sense at all. I felt at this point that any attempt to write phenomenologically was doomed to failure. My friends who saw me go to school every day kept asking me "How far are you with your writing Kalisha?" I'd mumble with words silently, "Here they go, not again". When I got home in the evening, my wife would ask, "Did you manage to do anything today?" Surely, after spending more than ten hours in school reading I should have managed to write something sensible. At that time, though, my stress levels were high; I felt that the words that I was writing were not making sense. I was reading and re-reading phenomenological texts that should shed light on the phenomenon, but I seemed to be going 
nowhere. I got more and more frustrated because there was no clear-cut set of rules for me to adapt and follow rhythmically to the end.

Ellen Bass (Linda, 2007, p. 5) writes a poem to her student Susan:

To my students

For Susan Lysik

You are concerned. Your writings

Are not poems - there are no line breaks

Sentences wind like coils of a pot

They are not stories - no beginning

Middle end, characters $\dagger$

Are not developed

The action is a child

Turning

In green chiffon

You apologize: I

Don't know what to call it

You want a name...

"Phenomenological language does not include self-contained names and concepts that can initially separate and define the phenomenon" writes Sævi (2013, p. 5). How was I to remain in touch with the phenomenon and attend to what it contained? There is an 'instrumental' desire among researchers to name the very thing that we are trying to grasp and write about. This desire pulls us to the brink of frustration because we crave for "certainty rather than messy exploration" (Linda, 2007, p. 8). Messy explorations seem to lead to unsure, unrealistic ends for which we are not prepared. Yet phenomenological writing is a "kind that needs a sufficiently slow pace for the writer to dwell with that which addresses her" (Sævi, 2013 , p. 6). The problem for me was that I wanted to know when I was being addressed by the phenomenon, and in my mind it was supposed to address me as fast as it could. The stress that accompanied this frustration was inevitable. When stressed one feels muscle aches and almost slowed breathing. An etymology of "stress" reveals an Old French word "estrece" meaning "narrowness, oppression" and a Latin word stringere, i.e., to "draw tight,"ix. At this point, I felt that the air of exploration and the beauty of meaning emerging from the explorations being made was tightened by my rigid desire for certainty.

The more I reflected, on the phenomenon of belonging -with a goal in mind to categorise it and speak to it,- to fashion it the way I want - the more it refused my categorisation; the more it became more indistinct, ambiguous and sometimes messy. At this point in my writing, I felt like I was "losing it." Sometimes I gave up and shred the draft which I had just written. However, as Friedman (quoted in Linda, 2007, p. 54) says, "give up, and the answer appears ... you are released"). I have read and re-read texts like that of van Manen, (2002), and Sævi, (2013), and seen the writerly struggles that appeal to an in-between writing, one that accepts to dwell, slowly and with hesitation in anxiety while at the same time waiting in pauses for the emergency of meaning. That I had seen them was slowly reaching me, aiding me.

Heidegger advises especially in the moment of anxiety, "We 'hover' in anxiety. More precisely, anxiety leaves us hanging because it induces the slipping away of beings as a whole... Anxiety robs us of speech", (Linda, 2007, p. 35). At the moment of anxiety, I feel burdened and overloaded by the desire to know what is going on and to know what the outcome will be. In such times, I have a vague idea that keeps on coming to mind but I do not 
know where this writing will lead me. When I am enveloped in the phenomenon which I am trying to describe in the moment of anxiety, I lose contact with all that I had before; I am no longer in control; it leads me on, asking me to see it as it is, describe it as it is without slipping away. It is this dwelling which catches one like a spell that made writing phenomenology lively for me, welled up meanings for me from the phenomenon itself, while at the same time making the act of writing worthwhile.

Phenomenological writing borders on what Heidegger calls techne. He says, Techne, as knowledge experienced in the Greek manner, is a bringing forth of beings in that, it brings forth what is present ... out of concealment and specifically into the unconcealment of its appearance; techne never signifies the action of making (Linda, 2007, p. 9).

The desire in writing, at least for me, is to arrive at a strategy, or a technique, one that I can be sure about and can rely on. Techne presupposes a desire to bring forth what is already present - what one has been seeing, feeling and sensing all along. It is not what is in the future or past, although this is included too. It is what is there. What is there reveals itself in part - a part that, perhaps we can fully grasp - yet it also hides itself in obscurity, a place where we no longer have access to it. This kind of seeing and reflecting phenomenologically on the phenomenon, sadly but truthfully "cannot be taught either in teaching or in writing", (Sævi, 2013, p. 5). All the teacher can do is to try as much as possible to deal carefully with the texts that a student of phenomenology produces. All she can do is to help the student intensify his or her reflections by offering suggestions and other possible ways of seeing. There is no proper way to start or end but to go on.

\section{Return to the call}

Rosemary and Stella were girls who appealed for my attention. They yearned for an adult who could see them for who they really are - human beings, incomplete, ambiguous and on the road to self-discovery. They needed someone they could talk with and someone who could listen to them. One who cared for them, one they could rely on. Their vulnerabilities reawakened in me the true meaning of encountering human beings. As Bollnow says, "In education a free human being [...] approaches another free being in a challenging way" (Bollnow quoted in Wivestad, 2008, p. 320). A free human being is used in Ahrenditian way to mean the essence of being human. The "challenging way" as used by Bollnow is one that does not see the other in the encounter as an outcome of a certain educative process, but sees the other as, like oneself, incomplete, ambivalent, ambiguous and in need of help. I used to see students as products of the education process, meaning whatever interaction I had with them was directed towards that end in mind. Yet, to children, this life is an end in itself (Van Manen 1991). I slowly came to the realization that I, too, am incomplete. The ambiguity of my interactions with others made me question my understanding of what it meant to be with children, to want to get involved in their daily trivialities. Their vulnerability made me become responsible for their needs, in a way understanding that my responsibility is nonreciprocal, irreversible and one-sided. This understanding freed me to keep asking myself, imagining what this or that situation is like for these girls. Words, phrases and experiences began to make more sense as I yearned to know what they meant for me and for the situations that I or my students were in. In a way, I tried to understand my own humanity as I tried to understand that of my students and thereby responded to the pedagogical call. 
${ }^{i}$ Dadaab refugee camp is located roughly five hundred kilometres from Nairobi and eighty kilometres from the Kenyan Somali border. It is the largest refugee settlement in the world with four refugee camps within it. Initially it was to hold 90,000 refugees but due to the continuous instability in Somalia, it currently holds 351,538 refugees (see UNHCR, 2015). Its nearness to Somalia places the refugees on the borderline, away from Kenyans and near their country of origin. This area is a desert, making learning conditions difficult.

ii Schools in Kenya are ranked according to performance. Those schools that perform well continuously for a long period are given the national ranking. Every province and district has its schools that are equally ranked according to performance. Selection of candidates to join these schools depends on their national tests at the end of primary school, where those with high grades go to national schools, with provincial and district schools receiving students progressively more poorly performing on those tests in that order. Therefore, district schools end up receiving those that have been rejected at all the other levels.

iii Didactic here is used with reference to a Scandinavian understanding of Didaktik, where upbringing and child is given precedence and is part of learning within and outside the classroom. See Biesta, 2011

iv The traditional punitive model that is described in this paper was observed in the refugee schools where I did my research.

${ }^{v}$ I came from a milieu that had adapted the Anglo-American tradition that sees education for what it can offer "what is the result"? Moreover, I crossed over to a European continental tradition that sees education as upbringing and part of the whole life of a child. I had also been used to a quantitative research mind-set rather than a qualitative and phenomenological one.

${ }^{v i}$ Other is used with a capital letter $\mathrm{O}$ as used by Levinas to mean "a personal other as distinguished from "other" with a lower case "o"... to mean otherness in general" see (Biesta, 2013, p. 19)

vii This anecdote is derived from my research data and has been used before to introduce an article of mine before, see (Kalisha, 2013a)

viii At this moment, I was at the Nordic African Institute in Uppsala Sweden for a one month writing scholarship, where I was writing my thesis.

ix Derived from www.etymonline.com

\section{References:}

Bachelard, G. (1964). The Poetics of Space. Boston Massachusetts: Beacon Press Books.

Biesta, G. J. (2013). The Beautiful Risk of Education. London: Paradigm Publishers.

Friesen, N., \& Irwin, S. (2014). “Being Online” Special Issue - Editors’ Introduction. Phenomenology \& Practice, 1-4.

Hansen, F. (2010). The Phenomenology of Wonder in Higher Education. In V. Herausgegeben, \& M. Brinkmann, Erziehung: Phänolomegische Perspektiven (pp. 161178). Könighausen \& Neuman.

Henriksson, C. (2008). Living AWAY from Blessing: School Failure as Lived Experience. Ontario, Canada: The Althouse Press.

Henriksson, C. (2012). Hermeneutic Phenomenology and Pedagogical Practice. In N. Friesen, C. Henriksson, \& S. Tone, Hermeneutic Phenomenology in Education; Method and Practice (pp. 119-137). Rotterdam, The Netherlands: Sense Publishers.

Henriksson, C., \& Sævi, T. (2009). "An Event in Sound" Considerations on the EthicalAesthetic Traits of the Hermeneutic Phenomenological Text. Phenomenology \& Practice, 3(1), 35-58.

Hove, H. P. (1999). Wonder and the Agencies of Retreat. Ottawa. Canada: University of Alberta- A Phd Dissertation. 
Kalisha, W. (2013a). Teaching for results or for well-being? To what Extent can pedagogical tact be an alternative teaching approach in Refugee secondary schools? A hermeneutic phenomenology inquiry into the lived experience of teaching refugee students in Dadaab refugee camp. International Journal of Teaching and Education, 1(1), 84-100.

Kalisha, W. (2013b). Belonging Pedagogically: The Lived Experience of Belonging in Pedagogical Encounters for Refugee Secondary School Girls and their Teachers in Dadaab Refugee Camp- Kenya. Bergen, Norway: Unpublished Masters Thesis at NLA University College.

Lewis, C. (2008). Alice's Adventures in Wonderland. Gutenberg: David Widger (Origanal published in 1865 by Macmillan \& CO.).

Linda, S. D. (2007). Dwelling in a Pedagogy of In-between: A Phenomenological Study of Teachers of Writing. College Park: Doctoral Dissertation at The University of Maryland, Unpublished.

Mollenhauer, K. (2014). Forgotten connections: On culture and upbringing. (N. Friesen, Trans.) New York: Routledge.

Nyathi, S. (2014, September 9). Meet. Retrieved from Book Shy Books blogspot: http://bookshybooks.blogspot.co.uk/p/meet.html

Ondaatje, M. (1987). In the Skin of a Lion. Toronto: McClelIand and Stewart.

Sævi, T. (2005). Seeing Disability Pedagogically- The Lived Experince of Pedagogy in Pedagogical Encounters. Bergen: Doctoral Thesis at the University of Bergen.

Sævi, T. (2011). Lived Relationality as Fulcrum for Pedagogical-Ethical Practice . Studies in Philosophy and Education, 455-461.

Sævi, T. (2012). Editorial. Phenomenology \& Practice, 6(1), 1-4.

Sævi, T. (2013). Between Beng and Knowing: Addressing the Fundamental Hesitation in Hermeneutic Phenomenological Writing. Indo-Pacific Journal of Phenomenology, 13(1), $1-11$.

Sævi, T. (2014, September 27). Phenomenology in Educational Research. Retrieved from Oxford Bibliographies: http://www.oxfordbibliographies.com/view/document/obo9780199756810/obo-9780199756810-0042.xml

UNHCR. (2015, $16^{\text {th }}-30^{\text {th }}$ April). Dadaab Refugee Camps, Kenya; UNHCR Bi-Weekly update. Geneva, Switzerland: UNHCR

Van Manen, M. (1984). Practicing Phenomenological Writing. Phenomenology + Pedagogy (Vol 2), pp. 36-69.

Van Manen, M. (1990). Researching Lived Experience: Human Science for an Action Sensitive Pedagogy. London, Ontario- Canada: Suny.

Van Manen, M. (2002). Writing in the Dark. London, Ontario: The Althouse Press.

Van Manen, M. (2003). Lived Experience. In L.-B. M, B. A.E, \& F. T. (Eds.), The Sage Encyclopaedia of social Science Research Methods (pp. 579-580). Oregon, OH: Sage Publication.

Wivestad, S. (2014). Klaus Mollenhauer's "Forgotten Connections:” A sketch of a general Pedagogic. Phenomenology \& Practice, 8(2), 7-12. 